\title{
ANALYSIS OF THE INVOLVEMENT OF PARTICIPANTS IN A SCHOOL-BASED PHYSICAL ACTIVITY PROMOTION PROGRAMME IN ADOLESCENCE
}

\begin{abstract}
The objective of this article is to evaluate "Sigue la Huella" ("Follow the Footprint"), a 2-year Spanish school-based physical activity promotion intervention, taking into account the viewpoints of the different agents involved. The evaluation entails a qualitative analysis of the strengths and weaknesses associated with the agents' participation, providing recommendations to improve the future application of this and other interventions. We draw on participatory research data collected through six focus groups with 35 participants (11 students, 14 teachers and 10 parents), semi-structured interviews with the two intervention facilitators, and an analysis of the strengths and weaknesses by the community advisory group.

The results of this study identify some recommendations that focus on a new policy proposal within the school context, driven by the responsible institutions, for the programme to improve the participation of the different stakeholders in future replication and institutionalisation efforts. In the opinion of all the participants, including stakeholders, the need for an organisational and cultural change in the schools is considered; one that will support Physical Education (PE) teachers in order for them to head this type of interventions and ensure their sustainability. Reference is also made to the need for school education projects, and for the effective collaboration between teachers and students, as well as their empowerment. Furthermore, greater engagement of all agents involved in promoting school physical activity (PA), especially among girls and older teenagers, parents and non-PE teachers, must be achieved.
\end{abstract}

Keywords: physical activity promotion, evaluation, adolescents, schools, sustainability 


\section{INTRODUCTION}

There is broad global consensus regarding the importance of physical activity (PA) for the positive development and well-being of young people (Beaulac, Olavarria and Kristjansson 2010), considering the school as a key strategic setting for its effective promotion (US Department of Health and Human Services, 2000). Socio-ecological models as well as global and participatory approaches are considered to be the most appropriate ways of achieving this (e.g., Van Sluijs, Griffin and Van Poppel, 2007), as they permit designing interventions aimed at empowering and engaging all agents and actors responsible for healthy and active lifestyles (Lounsbury and Mitchell, 2009).

With these principles in mind, the school physical activity promotion programme, Sigue la Huella ("Follow the Footprint"), implemented in the city of Huesca (region of Aragon, Spain) has been developed over a 3-school-year period. The intervention adopted a participatory action research approach (Baum, MacDougall and Smith, 2006), developed through the application of successive action-research cycles, and the co-construction of knowledge about PA (barriers, opportunities, etc.), and the intervention strategies adopted. This approach, used in other studies (e.g., Holt et al., 2013; Vecchiarelli et al., 2013), tries to capacitate and empower the school community participants (students, administrators, teaching and non-teaching staff, families), who are the experts in adolescents' health circumstances within their school contexts. A multisectoral group of stakeholders from the community, made up of the main PA promotion agents in the context, was also involved, as key actors who can facilitate and benefit from the intervention actions undertaken (Trembaly et al., 2018). The purpose was to create favourable environments for PA, and to empower students to actively participate and commit to the design and implementation of strategies and activities. The intervention strategies were divided into two channels (Murillo et al., 2018): a) Curricular, with 
tutorial action sessions led by the class tutors, and PE classes, aimed at fostering PA, enjoyment, and perceived competence in a participatory and supportive climate; and b) Extra-curricular, implemented through information dissemination activities aimed at the community, and with special community programmes and events. A facilitator, who was a member of the external research team, fostered collaboration among the working groups of students, teachers and families to design, implement and evaluate the intervention, trying, at the same time, to empower young people.

"Sigue la Huella" has proven to be an effective tool to increase daily levels of moderateto-vigorous PA, to reduce sedentary activity time, and to improve the results of motivational variables, and the predictors of moderate-to-vigorous PA and sedentary time among adolescents (Murillo et al., 2016). Moreover, since 2009, the "Sigue la Huella" project has been developed within the framework of the Health Promotion Project Network of Aragon, with adequate methodological development in its different phases (initial formative evaluation, implementation of participatory intervention strategies and actions, final evaluation, dissemination with translational evaluation). Consequently, the Directorate General for Public Health and Education (s.f.) considers this project to be extremely useful in establishing synergies and mechanisms to develop and evaluate public health PA promotion policies.

Therefore, the objective of this article was to evaluate the intervention, focusing on identifying, from the viewpoint of the different agents involved in the programme, the strengths and weaknesses associated with their participation, and to suggest recommendations that could be important to improve the future application of this and other interventions.

\section{METHOD}

Participants came from two Secondary Schools located in Huesca, a small-sized city (50,000 inhabitants) in the north of Spain. The schools (one public and one semi-private) were located in two different neighbourhoods, but with similar socioeconomic status (middle). Both 
schools were assigned as experimental groups of the intervention. Data collection for this evaluation was conducted within the 2 months following the end of the intervention (March 2012), using a variety of research techniques and participants to generate and triangulate data (Creswell, 2009).

Students, teachers and parents participated in focus groups organised separately for each profile. Participants were selected by means of purposive and non-random sampling, following a substantially diverse strategy to ensure maximum variation sampling, considering a representation of both male and female participants in each profile. Six focus groups, lasting for approximately 45 to 60 minutes, were conducted (two per profile), with four to seven participants each. In total, 35 participants took part: 11 students aged 14-15 years (6 boys, 6 girls); 10 parents ( 3 men, 7 women), and 14 teachers (5 men, 6 women).

The semi-structured script was developed based on key literature and with feedback provided by a qualitative researcher based on a first draft. It focused on: a) evaluating the involvement of the agents participating in the intervention (students, teachers and families) and the role of the facilitator; for example: 'How do you value the implications of families in the programme?', and b) identifying recommendations to be taken into account for future implementations and the sustainability of the programme. For example: 'What modifications are necessary to improve students' participation? How do you recommend continuing with the programme?'

The intervention facilitator of each school was interviewed individually for approximately one hour, using a semi-structured script that focused on analysing his/her general impression of the functioning of the programme, and the participation of the different agents, studying his/her own specific role in greater depth, and how his/her involvement evolved throughout the intervention.

The advisory group was comprised of 8 people with responsibilities at both provincial 
and local levels in areas associated with the intervention programme (e.g., education, sports, health), and whose task in the programme was to advise and facilitate the development of different initiatives within their areas of competence. All of them participated in a 2-hour interactive workshop led by the first author. After receiving information about the intervention results, the advisory group identified and analysed the strengths and weakness of the programme as well as ways for future improvements.

A previously trained 30-year-old women (first author) led all the data collection research sessions. These were presented to participants as part of the formative and participative efforts to promote PA in adolescents within a socio-ecological framework. All participants were volunteers, and in the case of the students, their parents' authorisation was also obtained. Participants remained anonymous and their details were considered as confidential. The study was reviewed and approved by the Ethics Committee for Clinical Research of Aragon (CEICA).

All the data collection sessions were audio-recorded and transcribed. A content analysis was performed with support from Atlasti 6.0 software, which followed a mixed deductive and inductive strategy procedure (Creswell, 2009). After multiple readings to become familiar with the data, a deductive logic was applied, based on selecting key information from the texts for the study purpose. Then, an inductive reasoning was used, similar to the constant comparative method of Glaser and Straus (1967), to analyse similarities and divergences of data, to identify the key issues within each main topic, and to organise them into a map of interrelated categories and subcategories meaningful to the study purpose (Table I).

\section{RESULTS}

Participation of students, parents and staff in the intervention programme.

Participation of students. The focus groups of parents, teachers and the students themselves acknowledged that the participation of students in the intervention was rather 
unequal (see Table II). First, it was acknowledged that involvement in the programme of students from higher classes (14 to 15-year-old students) was low. Possible reasons given were greater adolescent apathy, negative social influence of groups of friends, and lack of identification with the actual school. The low participation of girls in the programme, and in PA in general, is concerning, as pointed out by all participants in this study. As one teacher explained: 'I believe that girls are still a differentiating factor. You have to look at the playground, the girls walk around while the boys play. There's still a lot to be done in this regard (Teacher, School2).

As recommendations to improve the future involvement of students in the intervention (Table II), the students themselves and the teachers indicated the need to establish effective channels to empower students. Channelling the students' own initiatives and identifying student-leaders who can foster them, are mentioned as concrete measures to achieve this. Another proposal that emerged from the focus groups of teachers refers to the need to promote collaborative work proposals among teachers and students, with both groups participating together on an equal footing, breaking away from the traditional hierarchy that exists in the education system.

Finally, the focus groups of students and the analysis conducted by the advisory group point to the need to make efforts to promote PA, specifically in girls, proposing activities that consider their interests and preferences.

Participation of families. The collaboration of families in the development of the intervention was valued as very low. This has been attributed to a lack of communication between parents and students, and a possible lack of interest. As a recommendation to improve the involvement of this group (Table II), the parents themselves and the facilitators suggest the advisability of improving the communication channels with the family (e.g., over the school website or by e-mails), in addition to the collaboration of the Students' Parents Association 
(Spanish acronym, AMPA) to foster the participation of families in the programme.

Participation of staff. All participants in the study consider the action of PE teachers and of the tutors of the class groups targeted by the programme to be highly positive. In contrast, teachers, students and facilitators coincide in highlighting the lack of involvement of teachers of other subjects. This is perceived as very negative insofar as it represents a harmful and contradictory influence with respect to the PA promotion-focused educational message that they hope to pass on to the students. As one student stated: Yes, some of the school staff have promoted physical activity, with activities, fun breaktimes, trips. But there are also a considerable number of staff members who do not encourage doing sport or do sport, or who place you in context; so everything that some are doing well, is being undone by the others

\section{(Student, Sch 1).}

This lack of staff involvement is attributed to the parcelling of the curricular areas, to the lack of a collaborative culture at schools, which worsens in the case of temporary staff ( We are "watertight islands" and moreover "we adapt to our programme"), and to the lack of awareness of the teaching staff as a whole in terms of promoting PA, as this task is considered to be exclusive of the PE area.

To improve the involvement of teachers in successive implementations and to try to achieve the sustainability of the programme, teachers and facilitators refer to the need to foster collaborative work among teachers, which would make it possible to materialise interdisciplinary work proposals in the different curricular areas (Table II). To this end, emphasis is placed on the need to consolidate a school education proposal that will help to integrate the educational actions into the teachers' specific activities. Hence, as a strategy aimed at revitalising the previous activities, it is recommended for the intervention to be integrated within the School Education Project, as this would facilitate collaboration between the different areas, thus achieving the institutionalisation and appropriation of the programme by the 
participating school.

\section{Evaluation of the facilitator}

All participants in this study acknowledge that the action of the intervention facilitator in the different roles and activities developed was very positive, appreciating his/her degree of involvement, interest and continuity. However, this figure is also questioned by participants, as seen from the controversy surrounding two aspects: first, it is sustained that the programme has been possible thanks to the facilitator having "led" the other participants, to engage them in the programme. This aspect is considered as concerning, insofar as it generates a situation of dependence on this external agent, questioning the empowerment intended with the programme. As one teacher said: [Teachers] have possibly got involved because there were people who led the way for us, and that concerns me, it concerns me a lot. The project has been carried out and it has had an impact on the school, but because there were always people who have led the way for us (Teacher, Sch 2). But, the teachers also sustain that this initiative would not be possible without the continued involvement of this energising figure, due to the additional workload they consider that this task would represent. Another controversial aspect regarding the facilitator, and which is only mentioned by the actual facilitators, is associated with the segmentation or separation that exists among teachers from different curricular areas, which makes it difficult to get them involved in the programme.

As recommendations, the facilitators themselves and the teachers indicate that this must be a person who is integrated as a professional in the actual school (Table II). The facilitators point out that they should have the support of other profiles to facilitate the implementation of the intervention, such as a physical-sports activity organiser and a training advisor (undertaken by university personnel/researchers). Finally, they indicate the need for these different PA promotion profiles, and especially the intervention facilitator (as a teacher on the school staff), to be institutionalised figures, so they are acknowledged and supported by the education 


\section{DISCUSSION}

The efficacy of the "Sigue la Huella" programme in terms of PA variables (Murillo et al., 2016), together with the results of this study, which focuses on the opinion of the main programme participants, including the stakeholders, and the situational analysis of the institutions involved, permit the generation of a new proposal. This new proposal will include the creation of school and institutional policies that emerge from the results, by way of recommendations based on this study. Some of those presented herein focus on analysing school contexts, and others focus on the situational context, as institutional support will be necessary to carry out many of the recommendations or policies proposed within the school setting.

There is growing interest, today, in collaboration approaches to generate knowledge among users of knowledge and investigators, which lead to "co-designed" knowledge (VicHealth, 2018). This idea would be in line with some of the recommendations derived from the study results, such as identifying facilitator teachers and students who can promote initiatives. Achieving an effective co-design in health promotion has an enormous effect on empowering the communities involved (VicHealth, 2018). In this case, the adolescents and the entire educational community will want to engage in something they participate in, which they are familiar with and in which they feel they play an important role.

This study points to the need to motivate and specifically involve teenage girls, so intervention efforts that specifically address this group must be taken into account (e.g., Jago et al., 2012; Dewar et al., 2014). PA contexts frequently support gender stereotypes in ways that reinforce masculinity (e.g., power, strength and aggressiveness), and disadvantage most 
girls (Rauscher and Cooky, 2018). Moreover, conventional femininity continues to be linked to a lack of forceful actions, skilfulness and athleticism, and is internalised by the girls themselves. This stereotype could also act as an implicit barrier that limits girls' participation in PA (Rauscher and Cooky, 2018). Therefore, PA promotion programmes should be gendersensitive (Camacho-Miñano et al., 2011), guaranteeing that all students participate in them and enjoy them, and that they develop their physicality in a safe and non-threatening environment (Allender, Cowburn and Foster, 2006).

Another recommendation that emerges from the study results is related to the improvement in the communication of intervention actions or strategies. To this end, the visibility of the programme actions in the media -both traditional and social networks- could be intensified, using social marketing strategies (Berkowitz, Huhman and Nolin, 2008), taking advantage of the adolescents' environment (Huhman et al., 2009). Strategic alliances with parents' associations are also underscored as another key recommendation. Both actions should be especially aimed at strengthening the involvement of families, whose participation in the programme was very low. There is evidence that family support is consistently related to physical activity levels in adolescence (Mendoça et al., 2014), thus it is usually included in comprehensive school-based interventions (Carson et al., 2014). Although it is unclear how to make their participation effective, the different profiles of families should be considered (School State Council, 2014). The objective must be to seek realistic, flexible collaboration methods that can be adapted in time to ensure the sustainability of implemented actions (School State Council, 2014).

It is important to highlight that health-promotion and education strategies in a school setting essentially seek to strengthen and facilitate the educator's task, for him/her to be able to teach students the necessary life skills, to foster their basic competencies, and achieve adequate all-round development, thus achieving a positive impact on the health of the entire education 
community (Granizo and Gallego, 2007). Among school teachers, PE teachers are key figures in PA interventions (Webster et al. 2016; Grenier, Otis and Harvey, 2010). But, to achieve this, teachers must know how to tap into the existing social relations among young people, and to promote positive staff-youth connections (McDavid and McDonough, 2018). The results of this work indicate that these efforts must be carried out within an organisational and cultural change at schools, which unanimously supports PE teachers, for them to get involved and head (as facilitators) the development of PA promotion interventions, and to ensure their sustainability (Carson et al., 2014; Cardon et al., 2012). Therefore, the facilitator-investigator should progressively pass on the baton to another facilitator-teacher from the school; a person who is truly integrated into the school structure, and, at the same time, connected to researchers who evaluate the intervention (Langille and Rodgers, 2010; Van Acker et al., 2011).

But the staff context is not simple. The challenge of overcoming a sedentary lifestyle demands a global solution whose main premise is to generate synergies among all agents participating in the solution (Murillo et al. 2015a). Based on this idea, permanent education strategies, called "School Education Projects" in Spain, are proposed. This education must be based on the specific interests and needs of each school reality, and it must stimulate the reflection and autonomy of the teaching staff, favouring peer education and collaborative work in order to generate solutions to the real problems of the school throughout the formative process (Murillo et al. 2015). These education projects must also integrate external advice and support from the permanent education structures of the Administration.

The evidence presented in the article gives us the opportunity to introduce a translational formative evaluation, critical in successfully upscaling PA and health programmes (Nutbeam and Bauman, 2006). Thus, the new design of the "Sigue la Huella" programme will incorporate the recommendations detected, as well as the political and organisational context in which the successive implementations are going to be developed. For this reason, the community 
stakeholders have been considered from the onset as key figures to achieve this (Owusu-Addo et al., 2015). The aim is to improve the process of going from efficacy to scaled-up dissemination, reducing possible implementation problems, adding quality, scope and adaptation of translation into population-wide practice (O'Hara et al., 2014).

\section{CONCLUSION}

The results of the evaluation of this participatory research study suggest the need for an organisational and cultural change in schools to support Physical Education (PE) teachers in order for them to head this type of interventions and ensure their sustainability. School education projects that foster effective collaboration between teachers and students, and their empowerment, could be a key formative strategy, as well as improving the programme communication channels. Special efforts should focus on achieving greater engagement of low participation profiles, such as girls and older teenagers, parents and non-PE teachers. The engagement of stakeholders from the community, made up of the main PA promotion agents in the context, can facilitate and benefit from the intervention actions undertaken. This study highlights participatory research to co-construct, through alliances, the knowledge that is generated, to address issues related to improving the health of the education community, and to produce knowledge for mutual objectives.

\section{REFERENCES}

- Allender, S., Cowburn, G. and Foster, C. 2006. Understanding participation in sport and physical activity among children and adults: a review of qualitative studies. Health Education Research, 21, 826-835. doi:10.1093/her/cyl063

- Baum, F., MacDougall, C., and Smith, D. 2006. Participatory action research. Journal of Epidemiological Community Health, 60, 854-857. doi:10.1136/jech.2004.028662 
- Beaulac, J., Olavarria, M. and Kristjansson, E. 2010. A Community-based hip-hop dance program for youth in a disadvantaged community in Ottawa: implementation findings. Health Promotion Practice, 11(3Suppl), 61-69. doi:10.1177/1524839909353738.

- Berkowitz, J.M., Huhman, M., and Nolin, M.J. 2008. Did augmenting the VERB campaign advertising in select communities have an effect on awareness, attitudes, and physical activity? American Journal of Preventive Medicine, 34(6), 257-266. doi:10.1016/j.amepre.2008.03.005. - Camacho-Miñano, M.J.; LaVoi, N.M. and Barr-Anderson, D.J. 2011. Interventions to promote physical activity among young and adolescent girls: a systematic review. Health Education Research, 26, 1025-1049. doi:10.1093/her/cyr040

- Cardon, G.M., Van Acker, R., Seghers, J., De Martelaer, K., Haerens, L.L. and De Bourdeaudhuij, I.M.M. 2012. Physical activity promotion in schools: which strategies do schools (not) implement and which socioecological factors are associated with implementation? Health Education Research, 27, 470-483. doi:10.1093/her/cys043

- Carson, R.L., Castellli, D.M., Beighle, A. and Erwin, H. 2014. School-Based Physical Activity Promotion: A Conceptual Framework for Research and Practice. Child Obesity, 10, 100-106.

- Creswell, J.W. 2009. Research Design: qualitative, quantitative and mixed methods approaches. London: Sage.

- Dewar, D.L., Morgan, P.J., Plotnikoff, R.C., Okely, A.D., Batterham, M. and Lubans, D.R. 2014. Exploring changes in physical activity, sedentary behaviors and hypothesized mediators in the NEAT girls group randomized controlled trial. Journal Science and Medicine in Sport, 17(1), 39-46. doi:10.1016/j.jsams.2013.02.003

- Directorate General for Public Health and Education (s.f.). The Health Promotion Projects Network of Aragon. Retrieved from: https://www.aragon.es/organismos/departamento-de$\underline{\text { sanidad/servicio-aragones-de-salud. }}$ Accessed 13 September 2019 
- Glaser, B.G. and Straus, A.L. 1967. The discovery of grounded theory: strategies for qualitative research. Aldine, New York.

- Granizo, C., and Gallego, J. 2007. Criterios de calidad de la Red Aragonesa de Proyectos de Promoción de la Salud. Zaragoza, Gobierno de Aragón, Departamento de Salud y Consumo.

- Grenier, J., Otis, J. and Harvey, G. 2010. Faire équipe pour l'education à la santé en milieu scolaire. Press de 1’Université du Québec.

- Holt, N.L., McHugh, T.L.F., Tink, L.N., Kingsley, B.C., Coppola, A.M., Neely, K.C., and McDonald, R. 2013. Developing sport-based after-school programmes using a participatory action research approach. Qualitative Research in Sport, Exercise and Health, 5(3), 332-355. doi:10.1080/2159676X.2013.809377

- Huhman, M.E., Potter, L.D., Nolin, M.J., Piesse, A., Judkins, D.R., Banspach, S.W. and Wong, F.L. 2009. The influence of the VERB Campaign on children's physical activity in 2002 to 2006. American Journal of Public Health, 99(9), 1-9. doi:10.2105/AJPH.2008.142968

- Jago, R., Sebire, S.J., Cooper, A.R., Haase, A.M., Powell, J., Davis, L., ... Montgomery, A.A. 2012. Bristol girls dance project feasibility trial: outcome and process evaluation results. International Journal Behavioral Nutrition and Physical Activity, 9(1), 83-92. doi:10.1186/1479-5868-9-83

- Langille, J.L.D. and Rodgers, W.M. 2010. Exploring the influence of a social ecological model on school-based physical activity. Health Education \& Behavior, 37, 879-894. doi:10.1177/1090198110367877

- Lounsbury, D. W., and Mitchell, S.G. 2009. Introduction to special issue on social ecological approaches to community health research and action. American Journal of Community Psychology, 44(3-4): 213-220. doi:10.1007/s10464-009-9266-4

- McDavid, L. and McDonough, M. 2018. Staff perspectives on building social relationships with participants in a physical activity-based youth development program. Qualitative 
Research in Sport, Exercise and Health. doi:10.1080/2159676X.2018.1454977

- Mendoça, G., Cheng, LA., Nunes Melo, E. and Farias Júnior, J.C. 2014. Physical activity and social support in adolescents: a systematic review. Health Education Research, 29, 822-839. doi:10.1093/her/cyu017

-Murillo, B., Camacho-Miñano, MJ., Generelo, E., Julián, J.A., Novais, C. and Santos, P. 2015. Data for action: the use of formative research to design a school-based intervention programme to increase physical activity in adolescents. Global Health Promotion, 22, 45-54. doi: $10.1177 / 1757975914547202$

- Murillo, B., García Bengoechea, E., Julián, J.A. and Generelo, E. 2016. Motivational outcomes and predictors of moderate-to-vigorous physical activity and sedentary time for adolescents in the Sigue la Huella intervention. International Journal of Behavioral Medicine, 23, 135-142. doi:10.1007/s12529-015-9528-5

- Murillo, B., Julián, J.A., García, L., García, E. and Generelo, E. 2018. Development of the 'Sigue la Huella' physical activity intervention for adolescents in Huesca, Spain. Health Promotion International, 1-13. doi:10.1093/heapro/day005

- Nutbeam, D. and Bauman, A. E. 2006. Evaluation in a Nutshell: A practical guide to the evaluation of health promotion programs. McGraw Hill, Sidney.

- O’Hara, B. J., Phongsavan, P., King, L., Develin, E., Milat, A. J., Eggins, D., ... Bauman, A. E. 2014. "Translational formative evaluation": critical in up-scaling public health programmes. Health Promotion International, 29(1), 38-46. doi:10.1093/heapro/dat025

- Owusu-Addo, E., Edusah, S. E., and Sarfo-Mensah, P. 2015. The utility of stakeholder involvement in the evaluation of community-based health promotion programmes. International Journal of Health Promotion and Education, 53(6), 291-302. doi:10.1080/14635240.2015.1030033

- Rauscher, L. and Cooky, C. 2018. Sociological Dimensions of Girls Sport and Physical 
Activity. In Tucker Center for Research on Girls \& Women in Sport. (2018). The 2018 Tucker Center Research Report, Developing physically active girls: An evidence-based multidisciplinary approach (pp. 57-71). Tucker Center: Minnesota.

-School State Council. 2014. Participation of the families in the school education. Madrid: Minister of Education Culture and Sport.

- Tremblay, M.C., Martin, D.H., McComber, A.M., and Macaulay, A.C. 2018. Understanding community-based participatory research through a social movement framework: a case study of the Kahnawake Schools Diabetes Prevention Project. BMC Public Health, 18, 487-503. doi:10.1186/s12889-018-5412-y

- US Department of Health and Human Services. 2000. Healthy People 2020: understanding and improving health. 2nd ed. Washington, DC: US Government Printing Office.

- Van Acker, R., De Bourdeaudhuij, I., De Martelaer, K., Seghers, J., Kirk, D., Haerens, L., De Cocker, K. and Cardon, G. 2011. A framework for physical activity programs within school community partnerships. Quest, 63, 300-320.

- Van Sluijs, E. M., Griffin, S.J., and Van Poppel, M. N. 2007. A cross-sectional study of awareness of physical activity: associations with personal, behavioral and psychosocial factors. International Journal of Behavioral Nutrition and Physical Activity, 4, 53. doi:10.1186/1479$\underline{5868-4-53}$

- Vecchiarelli, S., Prelip, M., Slusser, W., Weightman, H., and Neumann, C. 2005. Using Participatory Action Research to Develop a School-based Environmental Intervention to Support Healthy Eating and Physical Activity. American Journal of Health Education, 36(1), 35-42. doi:10.1080/19325037.2005.10608154

-VicHealth, 2018. How co-design delivers agency, advocacy and real-world impact. Canada: VicHealth. Available from https://www.vichealth.vic.gov.au/letter/articles/vh-letter-45-codesign. Accessed 13 September 2019. 
- Webster, C.A., Russ, L., Webster, L., Molina, S., Lee, H. and Cribbs, J. 2016. PETE faculty beliefs concerning the preparation of preservice teachers for CSPAP roles: An exploratory study. Physical Educator, 73(2), 315-339. doi:10.18666/TPE-2016-V73-I2-6252 
Table I. Themes, categories and source of data.

\begin{tabular}{|c|c|c|c|c|c|c|}
\hline \multirow[b]{2}{*}{ Themes } & \multirow[b]{2}{*}{ Categories } & \multicolumn{5}{|c|}{ Source of data } \\
\hline & & $\begin{array}{l}\text { Students } \\
\text { FG } \\
(\mathrm{n}=2 ; 12 \\
\text { students })\end{array}$ & $\begin{array}{l}\text { Parents } \\
\mathrm{FG} \\
(\mathrm{n}=2 ; 10 \\
\text { parents })\end{array}$ & $\begin{array}{l}\text { Teachers } \\
\text { FG } \\
(\mathrm{n}=2 ; 14 \\
\text { teachers })\end{array}$ & $\begin{array}{l}\text { Facilitator } \\
\text { interview } \\
(\mathrm{n}=2)\end{array}$ & $\begin{array}{l}\text { Advisory } \\
\text { Group* } \\
\text { ( } \mathrm{n}=1 ; 8 \\
\text { participants) }\end{array}$ \\
\hline \multirow{2}{*}{$\begin{array}{l}\text { Perceived } \\
\text { participation } \\
\text { of students }\end{array}$} & $\begin{array}{l}\text { Level of participation } \\
\text { - Low participation of girls, older students } \\
\text { - Acceptable participation of younger } \\
\text { students and groups of friends }\end{array}$ & $\mathrm{X}$ & $X$ & $\mathrm{X}$ & $X$ & $X$ \\
\hline & $\begin{array}{l}\text { Recommendations } \\
\text { - Target girls } \\
\text { - Student empowerment } \\
\text { - Collaborative work with teachers }\end{array}$ & $\begin{array}{l}X \\
X\end{array}$ & & $\begin{array}{l}X \\
X\end{array}$ & $X$ & $X$ \\
\hline \multirow[b]{2}{*}{$\begin{array}{l}\text { Perceived } \\
\text { participation } \\
\text { of family }\end{array}$} & $\begin{array}{l}\text { Level of participation } \\
\text { - Very low participation }\end{array}$ & $X$ & $X$ & $X$ & $X$ & X \\
\hline & $\begin{array}{l}\text { Recommendations } \\
\text { - Improvement of communication channels } \\
\text { - Collaboration of AMPA (Parents' } \\
\text { Association) }\end{array}$ & & $\begin{array}{l}X \\
X\end{array}$ & & $\mathrm{X}$ & \\
\hline \multirow[b]{2}{*}{$\begin{array}{l}\text { Perceived } \\
\text { participation } \\
\text { of Teachers }\end{array}$} & $\begin{array}{l}\text { Level of participation } \\
\text { - High participation of PE teachers and } \\
\text { tutors } \\
\text { - Low participation of others teachers }\end{array}$ & $\mathrm{X}$ & $\mathrm{X}$ & $\begin{array}{l}X \\
X\end{array}$ & $\begin{array}{l}X \\
X\end{array}$ & $\begin{array}{l}\mathrm{X} \\
\mathrm{X}\end{array}$ \\
\hline & $\begin{array}{l}\text { Recommendations } \\
\text { - Collaborative work among teachers } \\
\text { (Interdisciplinary approach) } \\
\text { - Teacher's training at the school. } \\
\text { - Integration of the programme into the } \\
\text { PEC (School Curricular Project) }\end{array}$ & & & $\begin{array}{l}X \\
X \\
X\end{array}$ & $\begin{array}{l}X \\
X \\
X\end{array}$ & $\mathrm{X}$ \\
\hline \multirow[b]{2}{*}{$\begin{array}{l}\text { Evaluation } \\
\text { of the } \\
\text { facilitator } \\
\text { role }\end{array}$} & $\begin{array}{l}\text { Level of satisfaction } \\
\text { - Positive recognition } \\
\text { - Questioning of the facilitator's role }\end{array}$ & $X$ & & $\begin{array}{l}X \\
X\end{array}$ & $\begin{array}{l}\mathrm{X} \\
\mathrm{X}\end{array}$ & $\begin{array}{l}X \\
X\end{array}$ \\
\hline & $\begin{array}{l}\text { Recommendations } \\
\text { - Integration of the facilitator into the } \\
\text { school } \\
\text { - Support from other profiles } \\
\text { - Institutionalisation of profiles }\end{array}$ & & & $\begin{array}{l}\mathrm{X} \\
\mathrm{X} \\
\mathrm{X}\end{array}$ & $\begin{array}{l}\mathrm{X} \\
\mathrm{X} \\
\mathrm{X}\end{array}$ & $X$ \\
\hline
\end{tabular}

$\mathrm{FG}=$ Focus Groups; *= SWOT Analysis (the strengths, weaknesses, opportunities, and threats analysis. An analysis of the internal and external environmental factors performed as part of developing the organizational strategy) 
Table II. Suggested recommendations to improve the participation of the different participant profiles

\begin{tabular}{|c|c|c|}
\hline Profiles & Recommendations & Examples of quotations \\
\hline \multirow{3}{*}{ Students } & Target girls & $\begin{array}{l}\text { I believe that girls are still a differentiating factor. You just have to look at } \\
\text { the playground, the girls walk around while the boys play. There's still a lot } \\
\text { to be done in this regard (Teachers_Sch } 2 \text { ). }\end{array}$ \\
\hline & Student empowerment & $\begin{array}{l}\text { "[...] and in what way do we try to get students to manage themselves a bit } \\
\text { more so that we do not have to be continuously encouraging them" } \\
\text { (Teachers_Sch } 1 \text { ). }\end{array}$ \\
\hline & $\begin{array}{l}\text { Collaborative work with } \\
\text { the teachers }\end{array}$ & $\begin{array}{l}\text { "It is very important for both students and teachers to learn to work as a } \\
\text { group. That is very difficult. But, in other cases, we should learn, all of us } \\
\text { should know that the smallest cog in the wheel is important for the final } \\
\text { product" (Teachers_Sch_1). }\end{array}$ \\
\hline \multirow[t]{2}{*}{ Parents } & $\begin{array}{l}\text { Improvement of } \\
\text { communication channels }\end{array}$ & $\begin{array}{l}\text { "It could be interesting, to be able to have a greater influence, to post } \\
\text { everything about meetings on the website of the institute, apart from } \\
\text { sending e-mails and messages when there are activities" (Facilitator Sch 1). }\end{array}$ \\
\hline & $\begin{array}{l}\text { Collaboration of AMPA } \\
\text { (Parents' Association) }\end{array}$ & $\begin{array}{l}\text { "Talking about the parents, the AMPA could work to promote physical } \\
\text { activity and propose some activities of that kind." (Parents_Sch 1). }\end{array}$ \\
\hline \multirow{3}{*}{ Teachers } & $\begin{array}{l}\text { Collaborative work among } \\
\text { teachers (interdisciplinary } \\
\text { approach) }\end{array}$ & $\begin{array}{l}\text { "[...] more departments should get involved, but not just physical activity } \\
\text { (Teachers_Sch } 1) \text {. }\end{array}$ \\
\hline & $\begin{array}{l}\text { Teacher's training at the } \\
\text { school }\end{array}$ & $\begin{array}{l}\text { "The transformation into a school project with the increase of the number } \\
\text { of professionals involved in its development" (Advisory Group). }\end{array}$ \\
\hline & $\begin{array}{l}\text { Integration of the } \\
\text { programme into the PEC } \\
\text { (School Curricular Project) }\end{array}$ & $\begin{array}{l}\text { "We are really concerned about this dimension of promoting physical } \\
\text { activity from the schools and with the conviction that this has to be done } \\
\text { globally as the task is typical of an school education project" } \\
\text { (Facilitator_Sch 1). }\end{array}$ \\
\hline \multirow{3}{*}{ Facilitators } & $\begin{array}{l}\text { Integration of the } \\
\text { facilitator into the school }\end{array}$ & $\begin{array}{l}\text { "I believe that a facilitator has to be a professional that is in the school..." } \\
\text { (Facilitator_Sch } 2 \text { ) }\end{array}$ \\
\hline & Support from other profiles & $\begin{array}{l}\text { "Two years ago, the Ramón y Cajal secondary school had a person paid by } \\
\text { the council (social-cultural animator) for this function. In that circumstance, } \\
\text { with the students we have, it seems that this does represent change" } \\
\text { (Teachers_Sch 1) }\end{array}$ \\
\hline & $\begin{array}{l}\text { Institutionalisation of the } \\
\text { profiles }\end{array}$ & $\begin{array}{l}\text { "...but it must be a professional that everyone knows and, therefore, a } \\
\text { certain dedication is required" (Facilitator_Sch } 1 \text { ) }\end{array}$ \\
\hline
\end{tabular}

